\title{
Communication between Parents and Autistic Children to Gain Social Support
}

\author{
${ }^{1}$ HERNA, ${ }^{2}$ SARWITITI SARWOPRASODJO, \\ ${ }^{3}$ AIDA VITAYALA S. HUBEIS, ${ }^{4}$ HERIEN PUSPITAWATI \\ ${ }^{1}$ Sekolah Pascasarjana, IPB University, (Jl.Kamper, Babakan, Dramaga), Bogor, Jawa Barat \\ 2,3,4 Fakultas Ekologi Manusia, IPB University, (Jl. Kamper, Babakan, Dramaga), Jawa Barat \\ correspondence author: '1herna_12140@yahoo.com;
}

\begin{abstract}
The prevalence of autism among children in Indonesia during the last decade has been increased dramatically. This condition becomes a matter of concern because parents who raise children with autism experience stress and it is impacted their parenting. That situation is directly attributable to the fact that children with autism are often rigid and obsessive. Additionally, social stigma increases stress to parents of children with autism. This research aims to explore offline and online social supports for parents of children with autism. Targeted online social support sources are Facebook and WhatsApps Group. The research results show that the parents acquire offline social supports, especially from the nuclear family. Parents receive online social support that they could not fulfill offline and have benefited from online social media groups by getting information and emotional supports.
\end{abstract}

Keywords: social support, social media, autism

\section{Introduction}

The prevalence of Autism Spectrum Disorder (ASD) or known as autism has been increasing each year. According to the Centers for Disease Control and Prevention/ CDC, 1 out of 59 children is diagnosed with ASD. It is reported that autism could happen to any race, ethnic, and socio-economy groups (CDC-Centers for Disease Control and Prevention, 2019). Data from Departemen Pendidikan Nasional (National Education Departement) published in 2010 (in Riany et al., 2016) reported that in 2008, 638.000 children are diagnosed with autism in special schools in Indonesia and explained that the prevalence of autism among children is increasing to $15 \%$ each year.

Autism is a neurodevelopmental disorder characterized by social communication disorders, social skills, limited patterns, and atypical behaviour such as tantrum/ bad temper, aggressive, etc. (Achkova \& Manolova, 2014; Marrus \& Constantino, 2016). ASD diagnosis is identified in a spectrum or range based on American Psychiatric Association (2017), from high function autism to low function autism.

Other than behaviour and social communication problems, parents of children with ASD also suffered from stigma. The violation of social norms in a social situation can cause shame and may cause to exclusion from social activities, thus parents reluctant to interact with the surrounding environment. Access to education is also affected because of the stigma attached to children with ASD. Parents usually feel blamed when their autistic children show tantrums in public and often judged as a bad parent for children's atypical behavior, which caused a social exclusion. Pepperell et al. (2018) stated that parents of children with autism have higher stress compared to parents with normal children and even higher to parents who have children with other kinds of disabilities (Amireh, 2019).

The stigma surrounding autism is challenging. Parents of children with autism suffered from stress and anxiety to deal with

Received: 2020-01-01, Revised: 2020-05-30, Accepted: 2020-06-29. 
the symptoms and aggressive behaviour, a clinical treatment that takes time, expensive healthcare, and dealing with the uncertainty for their children's future because there is no cure for autism. (Ilias et al., 2018). These conditions encourage the parents to gain social support in form of information support, emotional support, and confirmation of place such as credible professionals (doctor/ psychologist) so that parents can get the best treatment for their children.

Parents seek social support through faceto-face (offline) and online communication. According to McIntyre \& Brown (2018), social support benefits the parents in giving treatment and caring for their autistic child. Valid and proper information regarding the treatment of children with autism leads to the increase of parents' abilities in managing their child atypical behaviour and also reducing stress. Parents with an autistic child also use social media to communicate with other parents who have the same experience. In this online community, parents have a sense of belonging to the community so that every parent can give the best treatment and care for their autistic child (Marasli et al., 2016; Buglass et al., 2017).

Social support from online and offline sources in this article is limited to the groups in Facebook/FB and WhatsApp Group (WAG) that specifically made for parents with autistic child. Facebook is the most used application globally with new 2,4 million users every month, while WhatsApp is ranked the third popular instant messaging application with 2 million users (We Are Social et al., 2020).

This article chooses a communication theory of Uses and Gratification Theory (UAG). UAG is evolving to adapt to the development of information communication technology (ICT) marked by the emergence of new media connected to the internet. The new media have unique characteristics that distinguish it from traditional media: interactivity, demassification, and asynchroneity. Interactivity is defined as the rate of active users (members of a group) in media exchanging roles within a group. Demassification is the ability of media users in selecting media that fulfill their needs and asynchroneity is an internet characteristic that enables the user to send, accept, save, and record messages with no time limitiation (Ruggiero, 2000).

The use of UAG can help in investigating communication situation mediated through one or several needs. This theory can also be used to analyze individuals' motivation in using social media to fulfill self gratifications such as social identity, information of interpersonal communication, interaction, etc. (Ruggiero, 2018). Moreover, UAG is proved as an effective approach in understanding social context as an important factor in communication. The researcher is able to explore interpersonal and qualitative aspects of society mediated by a holistic methodology.

The purpose of this article is to explore social support needed for parents with autistic child, both in offline and online channels, and to identify the type of information exchanged in the online channel. The novelty of this article is unraveling the new approach of UAG in terms of social media usage.

\section{Research Methodology}

This article assumes that development could happen subjectively based on individual interaction with its environment. This article used a qualitative approach by conducting in-depth interviews and observation to two groups of parents with autistic children in FB called "AUTISMA INDONESIA" and in WAG called "WAG ANAK ISTIMEWA"/WAG of special child. Purposive sampling is used in this research. In-depth interviews were conducted with four parents (two mothers and two fathers) who live in Jabodetabek (the acronym of Jakarta Bogor Depok Tangerang Bekasi), with different social economy level (upper middle class and lower middle class). The justification of this sampling is to explore the differences in overcoming anxiety for treating and caring children with autism and parent's motivation in seeking social support.

The observation was conducted by analyzing text, pictures, and videos uploaded in two groups selected between January 2020 to early February 2020. The FB group has 2.472 members, while the WAG group consists of 189 members. The reasons of group selection are based on Kozinet (2002) in (Nasrullah, 2018) which are: high interaction between members which is characterized by a high number of posts, have a variety of discussion topics, have rich data and information, and relevant to research questions.

Data analysis is conducted by building thematic codes related to social support such as informational support and emotional support. Relevant posts and comments were selected to support the coding process, 
which includes: information seeking, sharing experience, knowledge, giving supports and encouragement, and suggestions based on previous studies.

\section{Results and Discussion}

\section{The anxiety of Parents with Autistic Child}

Parents' motivation in seeking social support is determined by several factors: psychological, sociological, and cultural factors. Those factors include the perception of autism, parents' personality, faith in healing, independence of children in the future, and the belief that having children with autism is a gift from God. The majority of parents realized the physical symptoms showed by their children in their early age. Speech disorders, the absence of eye contact, repetitive behaviour (stimming), and also aggressive behaviour (tantrum) are symptoms of a child with autism. Parents, especially mothers, at first only identified the symptoms as normal disorders because of their limited knowledge about autism. Mother's concern about symptoms, disorders experienced by children, and the development of children who are left behind compared to other normal children is higher than that of fathers. This condition occurred because mothers have more interaction with children and directly experienced the stigma of children with autism.

Aggressive behaviour such as showing tantrums happened because of small problems. As quoted from an informant:

My child dislikes noises, (such as) sounds of children crying. He showed it by screaming, hitting, and intentions of biting so that he could harm others and himself. People do not understand about my child condition so they said my child have no manner, they even said my child as "insane"

(FT, BSD mother of child with autism, 4 years and 2 months old)

High-stress level suffered by mothers could lead to higher motivation in seeking support, such as seeking information about autism and how to overcome it; seeking emotional support through reinforcement by family or surrounding environment or people that shared the same experience. (Saha \& Agarwal, 2016) and Shepherd \& Parker (2017) stated that there is a significant correlation between symptoms of autism and parent's level of stress.

Parents with low social-economic levels have a higher stress level in giving treatment and caring for their autistic children. This is caused by the lack of access to resources. In contrast, parents that have access to resources have more ways in seeking information about the therapy, diet, vitamins, and tests (allergic test, hearing test) for their autistic children. The stress level is increased when parents can't fulfill their children's needs. An informant expressed that she/he can not give full attention to her/his child since she/he has to work from 7 to 5 . Work fatigue and lack of rest at home because they have to give attention to their children worsen the stress level. The informant also stated that they cannot leave work because of financial problems. This finding is in line with research by Kiami \& Goodgold (2017) conducted in Boston. The research revealed that mothers with autistic children have experienced stress caused by a lack of financial support and lack of sleep. Ilias et al. (2018) also stated that stress for parents is caused by the severity of autism symptoms, financial problems, parents' perception and their understanding to ASD, and anxiety for the children's future.

\section{Parents' face to face communication to gain support}

Offline support is defined as the main support from a spouse, nuclear family, extended family, professionals, and the surrounding environment. Interaction between parents and children can be used as a basis for anticipating behavior by finding information about symptoms and how to overcome them. Face-to-face communication with professionals (doctor or psychologist) is the first effort that can be done by parents in seeking for information about diagnosis or intervention needed for their children.

According to several informants, consultation with professionals in order to get diagnosis and intervention needed is faced with time limitations. Parents could not understand the explanation from professionals so that they need more information from online groups. In online groups, parents could discuss their problems and gets a suggestion from other members or clarifying information for credible sources from the group members. Cole et al. (2017) stated that parents express their willingness in getting more information about ASD and ways to treat their children through social media since they could not fully understand the explanation from professionals. However, (Zhang et al. (2016) revealed that social media is used by many users in seeking information about and related 
to health and also social support.

Family involvement in giving treatment and care for autistic children is much needed. Interpersonal communication with a spouse is the most important factor in accepting their children's condition so that spouses do not blame each other. It is important to explain children's condition to all family members to gain support. It is often found that parents, especially mothers, chose not to explain their children's condition or treatments suggested by professionals to other family members, even to spouses. This condition is caused by the personality of mothers and their cultural background. An interview with an informant (mother with 3 years old child) expresses her sadness when her mother-in-law blames her for her children haven't been able to talk like normal children do. This case showed the stigma experienced by parents. Parents is judged as bad parents because their 3 years old children can not talk yet, however, parents also chose not to explain to others about their children's condition.

The positive feeling expressed by all family members could be resources to overcome the stress experienced by parents and play an important role in giving social support in overcoming family problems. An informant stated that diet suggested by professionals as a treatment for their children is not working because there is no support from other family members. Mother with 5 years and 4 months old children revealed that she didn't tell her husband and other family members about diet for their children. One of the side effects of the diet is die-off (the release of toxins) symptoms where children became less active and languid when first implemented. The husband, looking at his child languid condition, decided to give food without knowing the diet intervention.

Furthermore, the informant also explained that the effort to gain support from the spouse is by explaining in detail about the diet, the benefit, and positive and negative impact about the diet. The informant also showed successful cases of using the same diet treatment for other autistic children to persuade her husband in supporting the diet. Not only her husband, she also explained it to other family members, colleagues, even neighbors that visited their house so that they stop giving wrong foods to their children. This explanation is quoted as below:

Special children also have special needs in food. 'Please stop giving foods that could be a toxic for their body', I often told that to my neighbours, friends of my children, or his/her grandma, but they answered 'we just give them a little, it looks like she/he want to eat this'. I tried to give more explanation, fortunately, the diet is going well.

(KD Bogor, mother of 5 years 4 months old autistic children)

The prime function of a family is giving social support to their family members. Family social support is the most influenced factors during stressful times when other people or relatives can not show support (Segrin \& Flora, 2017).

Several informants also stated the importance of face-to-face communication to explain their condition in gaining social support. Each family member should act as a place to solve problems or give support regarding the treatment of autistic children. The family also need to act like a team where communication and collaboration are encouraged to foster positive feeling in overcoming problems with autistic children. Through intense communication where family members can share information and express their opinions, emotions, and hope, social support is fostered. McIntyre \& Brown (2018) reveals that social support from family, friends, and community of parents with autistic children can give reinforcement from depression and anxiety suffered by parents.

Other types of offline communication chosen by parents with autistic children are attending groups meeting, such as therapy groups or seminars about therapy to increase their resources. An informant stated that she/he attended group meetings to gain knowledge about ASD for their children, for example, on how to independently implement a therapy so that they could have therapy at home. Through group meetings, parents also have the chance to interact with other people and gain support from people with the same experience. Banach et al. (2010) explained that mutual help, support, and reinforcement from the support-group could help parents in overcoming hard times. Through the support-group, parents are more empowered because they have more resources to ensure themselves in treating their own self and their children (Mukhtar, 2018).

\section{Visual Communication and Online Support}

Two reasons of why people seek social support in online platform because there 
are unfulfilled needs in offline platform or face-to-face communication or they only need additional support. Interview with an informant showed that they become a member of FB and WA group is because it is easy, cheap, and fulfill their needs in seeking information about treatment and care for autistic children. These two online groups is used as a platform to seek information about diet, ways for overcoming tantrum, stimming, stimulate veral, therapies, safe cooking tools, foods that give allergies, toilet training, vitamins, etc. Pew Research Center (2018) stated $67 \%$ of people gain information about ASD through online media.

Facebook is a social networking service that has "wall" that provide personal information and can be used to write status or post text, photos, and videos to the public, while WhatsApp is an instant-messaging application for smartphone where users could text online, share photos, videos, files, etc. These two social media have different ways in making or joining online groups (Apriani, 2017).

In Facebook, users can join a group by sending requests and then approved by the admin. In WAG, there are two ways in joining a group: adding contact number to group by the admin or through link provided in FB. There several rules and ethics that have to be followed by the members. The rules and ethics are made by the admin, such as users have to give comments in manner, no promotions, and focus on autism. Admin has the right to kick out users from the group for the sake of convenience of other members. These rules act as control social tools to enable a healthy discussion and information exchange for the members. These rules also need to be enacted to build a culture where members have to communicate humanly and provide a safe space for the members.

The result of the interview with several informants revealed several differences between the two social media. For FB, it needs to log in first, while WAG is not; the interaction in WAG is more intense because members posted more information and give more comments compared to FB Groups. Thus, it is concluded that WAG has higher interactivity compared to FB Groups, as explained by the statement below:

"I became a member of two private-groups
of Facebook and one WAG groups. I am more
active in WAG because I have access for 24
hours and the interaction is quicker (compared
to FB Groups). The member of WAG groups
gives more solutions, suggestions, and sharing
experience, also videos of successful therapy
that could be done at home. While in FB
Groups, this kind of support (from WAG) is
mixed with articles or news".

GK, Ciputat (mother of 5 years and a month-old autistic children)

FB provided a "like" button as a type of response, while in WAG users use emoji to give respond or reply. Table 1 summarizes the differences between FB and WAG for parents with autistic children.

The information-seeking patterns are done through posting questions, videos, photos, and then commented by other members in group. FB Groups and WAG become a place to discuss varieties of topics. The most discussed topics are diet and therapy. Other topics such as toilet training, fever treatment, vitamins are also discussed in the group. This interaction facilitated the

Table 1

Differences between FB Groups and WAG for Parents with Autistic Children

\begin{tabular}{lll}
\hline Aspect & Facebook & WAG \\
\hline Type of service & Social networking & Instant-messaging \\
"like" button & Available & Not available (use emoji in giving respond) \\
Way to join & Through friend requests & Added by admin or through link provided \\
Active & Have to be online & Could be seen offline \\
Login & Have to log in & No need to log in \\
$\begin{array}{l}\text { Number of posts in group } \\
\text { Number of comments in }\end{array}$ & Less & More \\
group & & More \\
Rate of giving comments & Slower & Faster \\
Symbols & "Like" button & Use emoji \\
\hline
\end{tabular}

Sources: (Research analysis results) 
development of belief and assurance, mutual support, and emotional support (Cheung et al., 2017). These two social media also give the same sense of togetherness that often felt in face-to-face communication, because the members felt that the online groups have influenced their life and fulfilled their needs. Roundtree (2017) also found that Facebook gives a sense of togetherness that fosters the emotional relationship between members of the group. Members of the group shared their experience about how hard it is to do the diet continuously, how to overcome this problem, and the group also made it possible to give comments to each other (Kamel Boulos et al., 2016; Cho et al., 2018).

Members of the group also shared their successful experiences to motivate each other in giving treatment to children with autism. Positive impacts from the diet for autistic children is shared through texts, photos, and videos. An informant express that his/ her children are no longer suffered from sleeping disorders, easy to focus, had longer eye contact, and no longer showing tantrums and stimming.

Other members also post videos about children's independency where children are watering flowers, eating without fed, showing verbal skills, playing puzzles, etc. This type of posts usually get compliments such as: "superb, handsome buy!", "Zidan is cool for helping mom in watering flowers", "you become smarter!", or responding by using emoji or like button that shows a positive reaction. Comments on the development of children's independence showed attention, empathy, thankfulness, also words of prayers that reinforce the encouragement. This support could also motivate and inspire other members to do the same.

Comments from practitioners regarding information or suggestion are categorized as informational support. This is in line with the research by Mohd Roffeei et al. (2015) who stated that there is support based on rationality, such as information and also physical support such as love, tolerance, encouragement, congratulations, gratitude, and words of prayers.

Members also share negative experiences in the groups. For example, the lack of support from spouse or family to do diet and the die-off side effects like languid, less active, fever, and thinner. Comments given to this negative experience are giving emotional support such as "break a leg!", "it's ok, its part of how the body reacts to the diet", "your child is not less active, but more focused!", etc. Comments came from other members that already experience the same problems. Comments from practitioners usually related to information about diet, its benefit, and its side effects. Both the emotional support and informational support help the members to gain confidence and give assurance about their efforts so that they feel safe to share their problems in the groups. Hård Af Segerstad \& Kasperowski, (2015) and Buglass et al. (2017) stated that the advantages of using social media other than cheap is less time consuming and become an arena for people with the same problems. Gage-Bouchard et al. (2017) revealed that exchanging experiences between people with the same problems or experiences related to health disorders leads to specific information of health.

The involvement of professionals in these social media groups is an important resource because members received suggestions and emotional support regarding treatment and care for children with autism. The relationship between professionals and other members of groups is equal and harmonic, where the professionals put themselves at the same levels as other members. This could be seen by several comments that add some hashtags like \#sekedaride (just giving you an idea) or \#sekedarsaran (just a suggestion). Research by Smailhodzic et al. (2016) stated that the relationship between professionals and members of a group in social media is equal.

Interaction in the social media groups has fostered open communication where it is stigma-free compared to real-life interactions. If users shared videos or photos about their children's achievements, other members will give them compliments and more encouragement as if the children are their own. The form of interactivity in social media groups is not only identified by the high number of posts and comments from the user but also how these posts and comments could lead to changes of behavior by the members.

The members also saved and recorded useful information or messages that could be shared or read in the future. In WAG, members could give a 'star' to mark important messages, such as "how to do toilet training through smart therapy session" and "how to make vegetable stock and meat". These messages are considered important because it is delivered by credible professionals. This 
habit is related to the characteristics of the internet stated by Ruggiero (2000) about asynchroneity where individuals can send, receive, save, and download a message to use in the future.

The summary of UAG analysis on health communication between parents with autistic children is presented in figure 1.

The existence of a visual community in social media could give solutions to parents in the form of seeking informational and emotional support. In summary, the type of online support and information exchanged is presented in Table 2.

Parents with autistic children fulfilling their needs of moral and mental support and hope from social media, yet the usage of social media also gives consequences. Inaccurate or invalid information is easy to find on the internet. A discussion about successful stories or cases might not be a good approach for other children. This may be caused by different clinical diagnoses for each child, so not all suggestions could work for all cases. The role of admin as a gatekeeper is also included in mediating debate regarding the differences of cases on children. This statement is supported by a quote below:

"This post is only for parents who chose to
diet certain foods, for others who do not do
this diet, then there is no problem. This is just
about choices. Please no more debate around
this matter. By saying that all autistic children
have to diet or not diet is not wise, as it is not
scientifically proven. For you who type this
kind of comment, make sure that you read this
post".
(DN Tangerang, father of 6 years old autistic
child).

much information and the risk of giving unproper suggestions or advice to members of groups are several negative impacts on using social media. Moorhead et al. (2013) stated that the bad effect of social media usage for health communication is the high risk of giving advice or suggestion that is not scientifically proven. Moreover, not all members participate actively due to many

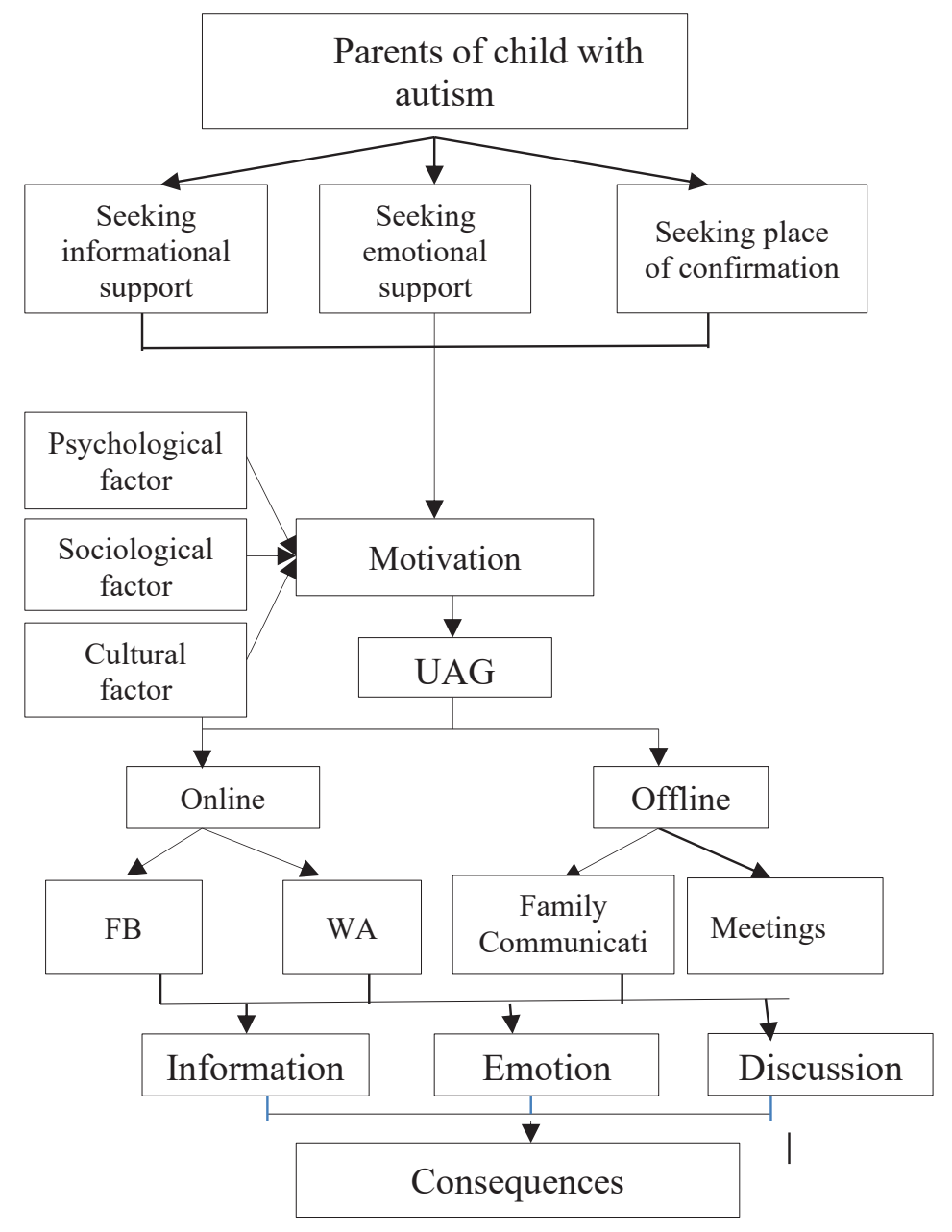

Figure 1. Summary of UAG Analysis on Health Communication Autism

Sources: (Research analysis results) 
Table 2

Type of Online Support and Information Exchanged on Social Media of FB Groups and WAG

\begin{tabular}{|c|c|c|}
\hline Type of support & Type of interaction & Example \\
\hline \multirow{4}{*}{$\begin{array}{l}\text { Place of confirmation (The } \\
\text { existence of professionals) }\end{array}$} & Giving suggestion and guidance & The positive and negative impact of diet \\
\hline & & How to do therapy at home \\
\hline & & Guidance on toilet training \\
\hline & & Shaping behaviour \\
\hline \multirow[t]{13}{*}{ Informational support } & Sharing experience & Diet of CFGFSF \\
\hline & & Diet of Kalsada (GAPS) \\
\hline & & Therapy \\
\hline & & How to overcome allergies \\
\hline & & How to overcome tantrum \\
\hline & Giving suggestion & Therapy places \\
\hline & & Doctor's recommendation \\
\hline & & School's recommendation \\
\hline & Knowledge-sharing & How to do therapy at home \\
\hline & & How to make children independent \\
\hline & & Toilet training \\
\hline & & How to stimulate sensory \\
\hline & & Safe cooking utensils \\
\hline \multirow[t]{5}{*}{ Emotional support } & Sympathy & \\
\hline & Empathy & \\
\hline & Exchanging words of prayer & \\
\hline & $\begin{array}{l}\text { Sharing children achievements } \\
\text { in visual form }\end{array}$ & \\
\hline & Reinforcement & \\
\hline
\end{tabular}

Sources: (Research analysis results)

reasons, such as discussion with boring contents, problems have already discussed in the groups and solution is already found, and also reluctant to share with strangers.

Dukungan sosial merupakan hadirnya orang-orang tertentu yang secara pribadi memberikan nasehat, motivasi, arahan dan menunjukkan jalan keluar ketika individu mengalami masalah dan pada saat mengalami kendala dalam melakukan kegiatan secara terarah guna mencapai tujuan (Bastaman, dalam Fatwa, 2014). Dukungan sosial sangatlah penting untuk dipahami karena dukungan sosial menjadi sangat berharga ketika individu mengalami suatu masalah oleh karena itu individu yang bersangkutan membutuhkan orang-orang terdekat yang dapat dipercaya untuk membantu dalam mengatasi permasalahannya tersebut. Dukungan sosial berperan penting dalam perkembangan manusia. Misalnya, orang yang relasi yang baik dengan orang lain, maka orang tersebut memiliki mental dan fisik yang baik, kesejahteraan subjektif tinggi, dan tingkat morbiditas dan mortalitas yang rendah (David \& Oscar, 2017)

\section{Conclusions}

Parents with autistic children need social support both informational and emotional in offline and online platforms in treating and caring for their children. Social support in an offline platform is needed from the spouse, nuclear family, professionals, and the surrounding environment. Social support in the online platform is also needed by parents with autistic children as additional support that they could not receive in real life. FB groups and WA groups for parents with autistic children are chosen by the parents because it is a safe place to discuss problems and gain more information regarding ASD from other members and professionals. 
Information and discussion about diet and therapy are the most talking issues other than toilet training, building children's independency, stimulating the sensory, safe cooking utensils, etc. Emotional support is also delivered by showing sympathy, empathy, and reinforcement. Social media groups foster togetherness and equality, just the same as real-life communication.

\section{References}

Achkova, M., \& Manolova, H. (2014). Diagnosis Autism - from Kanner and Asperger to DSM-5. Journal of Intellectual Disability - Diagnosis and Treatment. https://doi. org/10.6000/2292-2598.2014.02.02.4

American Psychiatric Association. (2017). DSM-5 Update. Diagnostic and Statistical Manual of Mental Disorder.

Amireh, M. M. H. (2019). Stress Levels and Coping Strategies among Parents of Children with Autism and Down Syndrome: The Effect of Demographic Variables on Levels of Stress. Child Care in Practice. https://doi.org/10.1080/13575279.201 8.1446907

Apriani, R. (Widyatama). (2017). Pengembangan Aplikasi Wedding Invitation Berbasis Kolaborasi Media Sosial.

Banach, M., Iudice, J., Conway, L., \& Couse, L. J. (2010). Family support and empowerment: Post autism diagnosis support group for parents. Social Work with Groups. https:// doi.org/10.1080/01609510903437383

Buglass, S. L., Binder, J. F., Betts, L. R., \& Underwood, J. D. M. (2017). Motivators of online vulnerability: The impact of social network site use and FOMO. Computers in Human Behavior. https:// doi.org/10.1016/j.chb.2016.09.055

CDC - Centers for Disease Control and Prevention. (2019). Data \& Statistics on Autism Spectrum Disorder | CDC. CDC. Gov.

Cheung, Y. T. D., Chan, C. H. H., Wang, M. P., Li, H. C. W., \& Lam, T. H. (2017). Online Social Support for the Prevention of Smoking Relapse: A Content Analysis of the WhatsApp and Facebook Social Groups. Telemedicine and E-Health. https://doi.org/10.1089/tmj.2016.0176

Cho, H., Silver, N., Na, K., Adams, D., Luong, K. T., \& Song, C. (2018). Visual cancer communication on social media: An examination of content and effects of \#Melanomasucks. Journal of Medical Internet Research. https://doi. org/10.2196/10501

Cole, L., Kharwa, Y., Khumalo, N., Reinke, J. S., \& Karrim, S. B. S. (2017). Caregivers of School-aged Children with Autism: Social Media as a Source of Support. Journal of Child and Family Studies. https://doi. org/10.1007/s10826-017-0855-9

Gage-Bouchard, E. A., LaValley, S., Mollica, M., \& Beaupin, L. K. (2017). Communication and Exchange of Specialized HealthRelated Support Among People With Experiential Similarity on Facebook. Health Communication. https://doi.org/1 0.1080/10410236.2016.1196518

Hård Af Segerstad, Y., \& Kasperowski, D. (2015). A community for grieving: Affordances of social media for support of bereaved parents. New Review of Hypermedia and Multimedia. https://doi. org/10.1080/13614568.2014.983557

Ilias, K., Cornish, K., Kummar, A. S., Park, M. S. A., \& Golden, K. J. (2018). Parenting stress and resilience in parents of children with autism spectrum disorder (ASD) in Southeast Asia: A systematic review. In Frontiers in Psychology. https://doi. org/10.3389/fpsyg.2018.00280

Kamel Boulos, M. N., Giustini, D. M., \& Wheeler, S. (2016). Instagram and WhatsApp in health and healthcare: An overview. In Future Internet. https://doi. org/10.3390/fi8030037

Kiami, S. R., \& Goodgold, S. (2017). Support Needs and Coping Strategies as Predictors of Stress Level among Mothers of Children with Autism Spectrum Disorder. Autism Research and Treatment. https://doi. org/10.1155/2017/8685950

Marasli, M., Sühendan, E., Yilmazturk, N. H., \& Cok, F. (2016). Parents' shares on social networking sites about their children: Sharenting. Anthropologist. https://doi. org/10.1080/09720073.2016.11892031

Marrus, N., \& Constantino, J. N. (2016). Autism spectrum disorders. In The Curated Reference Collection in Neuroscience and Biobehavioral Psychology. https:// doi.org/10.1016/B978-0-12-8093245.23581-5

McIntyre, L. L., \& Brown, M. (2018). Examining the utilisation and usefulness of social support for mothers with young children with autism spectrum disorder. Journal of Intellectual and Developmental Disability. https://doi.org/10.3109/13668250.2016. 1262534

Mohd Roffeei, S. H., Abdullah, N., \& Basar, S. K. R. (2015). Seeking social support on Facebook for children with Autism 
Spectrum Disorders (ASDs). International Journal of Medical Informatics. https:// doi.org/10.1016/j.ijmedinf.2015.01.015

Moorhead, S. A., Hazlett, D. E., Harrison, L., Carroll, J. K., Irwin, A., \& Hoving, C. (2013). A new dimension of health care: Systematic review of the uses, benefits, and limitations of social media for health communication. In Journal of Medical Internet Research. https://doi. org/10.2196/jmir.1933

Mukhtar, D. (2018). Pengaruh GroupBased Parenting Support terhadap Stress Pengasuhan Orang tua yang Mengasuh Anak dengan Gangguan Spektrum Autis.

Nasrullah, R. (2018). Etnografi Virtual. Riset Komunikasi, Budaya dan Sosioteknologi di Internet (Vol. 2).

Pepperell, T. A., Paynter, J., \& Gilmore, L. (2018). Social support and coping strategies of parents raising a child with autism spectrum disorder. Early Child Development and Care. https://doi.org/ 10.1080/03004430.2016.1261338

Pew Research Center. (2018). Social Media Use in 2018. Pew Research Center.

Riany, Y. E., Cuskelly, M., \& Meredith, P. (2016). Cultural Beliefs about Autism in Indonesia. International Journal of Disability, Development and Education. https://doi. org/10.1080/1034912X.2016.1142069

Roundtree, A. K. (2017). Social health content and activity on facebook: A survey study. Journal of Technical Writing and Communication. https://doi. org/10.1177/0047281616641925

Ruggiero, T. E. (2000). Uses and Gratifications Theory in the 21 st Century. Mass Communication and Society. https://doi. org/10.1207/s15327825mcs0301_02

Ruggiero, T. E. (2018). Uses and Gratifications Theory in the 21st Century. In Refining Milestone Mass Communications Theories for the 21st Century. https://doi. org/10.4324/9781315679402-4

Saha, A., \& Agarwal, N. (2016). Modeling social support in autism community on social media. Network Modeling Analysis in Health Informatics and Bioinformatics. https://doi.org/10.1007/s13721-0160115-8

Segrin, C., \& Flora, J. (2017). Family conflict is detrimental to physical and mental health. In Communicating interpersonal conflict in close relationships: Contexts, challenges, and opportunities.

Shepherd, N., \& Parker, C. (2017). Depression in adults: Recognition and management. Clinical Pharmacist. https://doi. org/10.1211/CP.2017.20202439

Smailhodzic, E., Hooijsma, W., Boonstra, A., \& Langley, D. J. (2016). Social media use in healthcare: A systematic review of effects on patients and on their relationship with healthcare professionals. BMC Health Services Research. https://doi. org/10.1186/s12913-016-1691-0

We Are Social, Hootsuite, \& DataReportal. (2020). Most popular social networks worldwide as of January 2020, ranked by number of active users (in millions). Statista. Statista Inc.

Zhang, L., Zhao, J., \& Xu, K. (2016). Who creates Trends in Online Social Media: The Crowd or Opinion Leaders? Journal of Computer-Mediated Communication. https://doi.org/10.1111/jcc4.12145 